\title{
Do breeds of pig differ in the efficiency with which they use a limiting protein supply?
}

\author{
BY I. KYRIAZAKIS AND G. C. EMMANS \\ (with the technical assistance of D. H. ANDERSON) \\ Genetics and Behavioural Sciences Department, SAC, West Mains Road, Edinburgh EH9 3JG
}

(Received 14 April 1994-Revised 23 November 1994-Accepted 15 December 1994)

\begin{abstract}
An experiment was designed to test the prediction that two genetically-very-different kinds of pigs would retain the same amounts of protein in their bodies when given the same allowances of the same feed for the same period of time, when these allowances were limiting for both. An allowance of $33.957 \mathrm{~kg} \mathrm{of} \mathrm{a}$ feed with 12.76 MJ metabolizable energy (ME) and $189 \mathrm{~g}$ crude protein $(\mathrm{N} \times 6.25) / \mathrm{kg}$ feed was given to Large White $\times$ Landrace ( $L W \times$ ) and Chinese Meishan (CM) female pigs over three different periods of time: (1) ad lib. (AL) with the time taken by individual pigs to consume the allowance being a variable, (2) over a period of 7 weeks $(\mathrm{H})$ and (3) over a period of 9 weeks (L). In addition, in a fourth treatment, pigs of both breeds received the same allowance but supplemented with starch also over a period of 7 weeks (HS). The performance of the pigs on treatment AL was affected by pig breed, with CM pigs gaining protein at a slower, and lipid at a faster, rate than $L W \times$ pigs. On treatments $L, H$ and $H S$ the average amounts of protein retained were 2.693 and $2.655 \mathrm{~kg}$ for the $L W \times(n 15)$ and $C M(n 15)$ pigs respectively (SED $0.106 \mathrm{~kg}$ ). There was a statistical indication that the $L W \times$ pigs may have been more efficient on $L$, and less efficient on HS, than the CM pigs but we have been unable to propose any biological reason for such an effect, if it was in fact a real one. Thus, the efficiency with which ideal protein was utilized was close to being constant, and apparently at its maximum, for the two breeds. However, although $\mathrm{CM}$ pigs had the same protein gain, and the same live weights, on the same feed allowances as the $\mathrm{LW} \times$ pigs, they gained significantly more lipid. This was attributed in part to their digesting their feed better and in part to their having a lower energy requirement for maintenance through a lower level of physical activity. Given that these two very different kinds of pigs use limiting protein with the same efficiency, it is suggested that it is safe to make the assumption in models of pig growth that the material efficiency of using limiting protein is constant across genotypes of pig.
\end{abstract}

Growth model: Meishan pigs: Pig breeds: Protein utilization

The efficiency with which a limiting resource, such as protein, will be used by an animal, or by a human being, is the key both to predicting the performance to be expected from a given diet and also to calculating the requirement for some level of performance to be attained. In the specific case of a pig growth model the central problem, which is closely connected with that of the efficiency of the use of protein, is that of predicting the rate at which a pig will retain protein in its body, $P R(\mathrm{~kg} / \mathrm{d})$, from information on the diet that it is given, including both its composition and the rate at which it is fed.

Whittemore \& Fawcett (1974), in a model that has had considerable influence, proposed that within a live-weight range such as $20-100 \mathrm{~kg}$ a pig had a genetic maximum rate of protein retention, $P R_{g}(\mathrm{~kg} / \mathrm{d})$, the value of which would vary between kinds of pig. Whether this rate would be attained, or not, in a given case was predicted by their model from a knowledge of the diet. The maximum rate of protein retention allowed by the diet, $P R_{d}$ $(\mathrm{kg} / \mathrm{d})$, was calculated as the ideal protein supplied by the diet after subtracting a 
maintenance allowance, i.e. ideal protein was assumed to be used with perfect efficiency for growth. Whittemore \& Fawcett (1976) modified their earlier model by proposing a constraint on the minimum value of the lipid:protein ratio in the gain. Where the conditions were such that this constraint did not operate, $P R$ was still predicted as the lesser of $P R_{d}$ and $P R_{g}$. They found that this modification was needed to predict the results of experiments in which pigs were given low allowances of foods of high protein content.

The models of Whittemore \& Fawcett $(1974,1976)$ have since been modified in a number of important ways. First, the value of $P R_{g}$ has been made to vary with the protein weight, $P(\mathrm{~kg})$, of the pig rather than being set as a constant over a given weight range (Whittemore et al. 1988; Whittemore, 1994). Second, the ideal protein supplied above maintenance has been seen as being used with a material efficiency, $e_{p}$, which may be less than unity. Kyriazakis \& Emmans $(1992 a, b)$ proposed that the value of $e_{p}$ is directly proportional to the energy: protein ratio of the feed, $R(\mathrm{MJ}$ metabolizable energy $(\mathrm{ME}) / \mathrm{kg}$ digestible crude protein (DCP)), up to some maximum value which is less than unity. Third, given this view of $e_{p}$, the idea of a minimum lipid:protein ratio in the gain has proved to be an unnecessary one (Kyriazakis et al. 1994) and this constraint has been dropped.

In the modified model $P R_{g}$ is made a function of $P$ through two variables, $P_{m}$ and $B$, the values of which are variable between pigs (Emmans, 1988); the form of the function is $P R_{g}(\mathrm{~kg} / \mathrm{d})=P . B . \log _{\mathrm{e}}\left(P_{m} / P\right)$, where $P_{m}(\mathrm{~kg})$ is the (mature) protein weight at which $P R_{g}$ becomes zero and $B$ is a rate variable, $(/ \mathrm{d})$. A further strong assumption is that, for a feed with a given value of $R$, the value of $e_{p}$ is the same for all pigs (Kyriazakis \& Emmans, $1992 \mathrm{~b}$ ). It follows that, on a common diet which does not allow $P R_{g}$ to be attained by any one of a set of pig genotypes, the $P R$ of all of them will be the same. The results of experiments designed to test this strong assumption were consistent with it. Kyriazakis \& Emmans ( $1992 b$ ) found no differences between males and females of a given kind of pig in the value of $e_{p}$ on a given limiting diet and Kyriazakis et al. (1994) found no difference in $e_{p}$ between the pigs of two very different breeds, a Large White $\times$ Landrace $(\mathrm{LW} \times)$ and a Chinese Meishan (CM).

The assumptions underlying the modified model described previously do not have universal support and there are competing views in the field (see Campbell \& Taverner, 1988; Fuller \& Garthwaite, 1993). There is no unanimity in the view that different genotypes will retain protein at the same rate on a diet that is limiting for all.

In the experiment of Kyriazakis et al. (1994) the two breeds of pigs were, for good reason, not given the same allowances of the same feed. The purpose of the experiment to be described here is, by using a different design, to test in a more straightforward way the strong assumption that, when given the same allowance of the same feed in the same time, a diet which limits the protein retention of both, the two kinds of pig will retain the same amount of protein. The genetic variable is pig breed but the results may also be relevant to the more general question of whether requirements determined on one population, whether animal or human, can be assumed to be applicable to others.

\section{MATERIALS AND METHODS}

Animals and housing

Forty-nine female pigs were received immediately after weaning at between 4 and 5 weeks of age from the Cotswold Pig Development Company Ltd (Lincoln, Lincs.). Twenty-six of them were $\mathrm{F} 1$ hybrid $\mathrm{LW} \times$ and twenty-three were pure-bred $\mathrm{CM}$. On arrival they were moved into the individual cages of the experimental unit, which has been described previously (Kyriazakis \& Emmans, 1992a); the pigs were allocated to the individual cages of the unit at random. The weaned LW $\times$ and CM pigs, which had mean live weights of 
Table 1. The composition and chemical analysis of experimental feeds $B$ and $S$ $(\mathrm{g} / \mathrm{kg}$ fresh feed $)$

\begin{tabular}{|c|c|c|}
\hline Feed... & B & $\mathbf{S}$ \\
\hline \multicolumn{3}{|l|}{ Ingredient ( $\mathrm{g} / \mathrm{kg})$} \\
\hline Micronized wheat & $681 \cdot 4$ & $463 \cdot 2$ \\
\hline Fishmeal & 60 & 40 \\
\hline Hipro soyabean meal & 180 & 120 \\
\hline Maize oil & 28.5 & $34 \cdot 3$ \\
\hline DL-Methionine & 1.6 & $1 \cdot 1$ \\
\hline Dicalcium phosphate & $28 \cdot 5$ & $37 \cdot 7$ \\
\hline Salt & - & $0 \cdot 2$ \\
\hline Vitamin and mineral supplement & $20 \cdot 0$ & $20-0$ \\
\hline \multirow[t]{2}{*}{ Starch } & - & $283 \cdot 5$ \\
\hline & $1000 \cdot 0$ & $1000 \cdot 0$ \\
\hline \multicolumn{3}{|l|}{ Component $(\mathrm{g} / \mathrm{kg})$} \\
\hline Dry matter & 876 & 870 \\
\hline Crude protein $(\mathrm{N} \times 6.25)$ & 189 & 142 \\
\hline Crude fibre & 43 & 30 \\
\hline Diethyl ether extract & 39 & 40 \\
\hline Ash & 67 & 74 \\
\hline Starch & 381 & 453 \\
\hline Metabolizable energy $(\mathrm{MJ} / \mathrm{kg})^{*}$ & $12 \cdot 8$ & $12 \cdot 9$ \\
\hline Gross energy $(\mathrm{MJ} / \mathrm{kg})$ & $16 \cdot 1$ & $15 \cdot 6$ \\
\hline
\end{tabular}

* Calculated by the European Association of Animal Production Working Group equation (Batterham, 1990).

Table 2. The allowances $(\mathrm{g} / \mathrm{d})$ of the experimental feeds on the four treatments in which total allowance of feed $B$ was given over three different periods of time: ad lib. $(A L)$, over a period of 7 weeks $(H)$ and over a period of 9 weeks $(L)$ and an allowance of feed $S$ was given over 7 weeks $(H S)$ to Large White $\times$ Landrace and Chinese Meishan pigs

\begin{tabular}{|c|c|c|c|c|}
\hline \multirow{2}{*}{$\begin{array}{l}\text { Feed*... } \\
\text { Treatment ... }\end{array}$} & \multicolumn{3}{|c|}{ B } & \multirow{2}{*}{$\begin{array}{c}\mathrm{S} \\
\mathrm{HS}+\end{array}$} \\
\hline & $A L$ & $\mathrm{~L}$ & $\mathrm{H}$ & \\
\hline Week: 1 & Variable & 299 & 393 & $589 \cdot 5$ \\
\hline 2 & Variable & 359 & 493 & $739 \cdot 5$ \\
\hline 3 & Variable & 419 & 593 & 889.5 \\
\hline 4 & Variable & 479 & 693 & $1039 \cdot 5$ \\
\hline 5 & (Variable) & 539 & 793 & $1189 \cdot 5$ \\
\hline 6 & - & 599 & 893 & $1339 \cdot 5$ \\
\hline 7 & - & 659 & 993 & 1489.5 \\
\hline 8 & - & 719 & - & - \\
\hline 9 & - & 779 & - & - \\
\hline Total allowance $(\mathrm{g})$ & 33957 & 33957 & 33957 & $50935 \cdot 5$ \\
\hline Period of time (d) & Variable & 63 & 49 & 49 \\
\hline Feed allowance $(\mathrm{g} / \mathrm{d})$ & Variable & 539 & 693 & $1039 \cdot 5$ \\
\hline
\end{tabular}

* For details of composition, see Table 1.

$\dagger$ The allowance of protein was the same as for treatment $\mathrm{H}$. 
8.27 (SD 0.396) and 8.66 (SD 0.551) kg respectively, were given free and continuous access to a high-quality commercial feed (Dalgety Agriculture Ltd, Bristol, Avon; 300 Ultra Start pellets).

\section{Experimental feeds}

A feed, B, based on micronized wheat, high-protein soyabean meal and fishmeal, with an estimated energy content of $12.8 \mathrm{MJ} \mathrm{ME}$ and a crude protein $(\mathrm{N} \times 6.25 ; \mathrm{CP})$ content of $189 \mathrm{~g} / \mathrm{kg}$ was formulated (Table 1). The feed was abundant, based on Agricultural Research Council (1981), in minerals and vitamins. A second feed, S, was also made which had 0.66 of the CP content of feed B and similar energy, minerals and vitamin contents (Table 1). Maize starch (Cerestar GL 03403; Cerestar UK Ltd, Manchester) was the major diluent of feed $\mathbf{B}$ used to achieve the specifications of $\mathbf{S}$. The calculated amino acid contents of the protein $(\mathrm{g} / \mathrm{kg} \mathrm{CP})$ of the feeds used were: lysine $53 \cdot 2$, methionine +cystine $40 \cdot 2$, threonine $36 \cdot 8$, tryptophan $12 \cdot 4$. Comparison of these values with those for the ideal protein as given by Agricultural Research Council (1981) showed that lysine was the first limiting amino acid and that the value of the protein was 0.76 of the ideal.

The ME:DCP value in feed $B$ was well above the critical point of $72.5 \mathrm{MJ} / \mathrm{kg}$, estimated to be needed for the maximum efficiency of the use of ideal protein above maintenance by Kyriazakis \& Emmans (1992b) and Kyriazakis et al. (1994).

\section{Design}

As each of the pigs reached $16 \mathrm{~kg}$ live weight it was assigned at random either to an initialslaughter group or to one of four feeding treatments (Table 2). The four feeding treatments supplied the same amount of protein to all pigs, but this was given in four different ways. In three of the four treatments the pigs were given the same total allowance of feed B, $33.957 \mathrm{~kg}$, but over three different periods of time which were: (1) ad lib. (treatment AL) with the time taken by individual pigs to consume this amount therefore a variable, (2) over a period of 7 weeks (treatment $H$ ) or (3) over a period of 9 weeks (treatment $L$ ). The period of 7 weeks was calculated to be the shortest that could safely be assumed to limit the protein growth rate of the CM pigs. The amount of $33.957 \mathrm{~kg}$ was carefully chosen so that (1) it would be consumed by the AL pigs in approximately 4 weeks, (2) when given over a 7 -week period would allow the CM pigs to attain a rate of protein retention of about 0.90 of their maximum rate, and (3) it was divisible by both 7 and 9 , since the allowances offered to the pigs were changed weekly on the linear scales shown in Table 2 . The fourth treatment, HS, was an allowance of feed $\mathrm{S}(50.9355 \mathrm{~kg}$ which is $1.5 \times 33.957 \mathrm{~kg})$ over a period of 7 weeks; the daily allowances offered to these pigs were also changed weekly on the linear scale shown in Table 2. In this way pigs on treatment HS were given the same amount of protein as those on treatments $\mathrm{AL}, \mathrm{H}$ and $\mathrm{L}$, but this was with additional energy. This design was seen as being more straightforward for comparing the breeds than alternatives where they were compared over equal weight ranges or were to be fed according to weight rather than time.

The initial intention was to allocate five pigs per breed to each of the four feeding treatments and the initial-slaughter group (a total of twenty-five pigs per breed). This number of animals, given the variability seen in earlier studies (Kyriazakis et al. 1994), gave the present study sufficient power to detect a mean difference between the breeds of $10 \%$ in protein gain on the limiting treatments. This was achieved with the available number of $\mathrm{LW} \times$ with the extra pig being allocated to the initial-slaughter group to avoid unbalancing the design, but we were two CM pigs short. It was decided to allocate four CM pigs to each of the two least important treatments (i.e. the initial-slaughter and AL groups) and five CM pigs to each of the other treatments, in order to have equal numbers of both breeds on these 
critical treatments. In the event, by mistake, there are four CM pigs on $\mathrm{L}$ and six on HS. The pigs were slaughtered either at the start of the experiment (initial-slaughter group) or at the end of each relevant period.

\section{Management and slaughter procedures}

The management and slaughter procedures were similar to those described in previous experiments (Kyriazakis \& Emmans, 1992 a, b; Kyriazakis et al. 1994). Pigs were fed twice daily (at 08.30 and 17.00 hours) and weighed once weekly before feeding. Effort was made to collect any feed spillage on trays under the feed troughs. Feed refusals were collected and weighed daily, and for the three restricted-feeding treatments $(H, L$ and $H S)$ any amounts of feed equivalent to the refusal and the estimated spillage re-fed later to the animals in addition to their set allowances. On the day before slaughter the pigs were fed normally, and on the following morning were weighed and killed by an injection of Pentobarbitol sodium. Samples of their complete empty bodies were analysed for dry matter (DM) and for the $\mathrm{N}$, ash and gross energy (GE) contents of the dry matter.

The ambient temperature was gradually reduced from $28^{\circ}$, when the pigs were first moved, to $22^{\circ} 2$ weeks later when the feeding treatments started, at which level it was held constant until the end of the experiment. This temperature was believed to be higher for the ad lib-fed pigs than they needed to attain their potential rate of protein retention, but was thought to be necessary to prevent the most-restricted-fed pigs being cold.

\section{Analysis of the results}

Whenever there were some cumulative refusals of the offered diets, these were measured and used in the analysis of the results. Comparisons of the body compositions, and of the gains of body components, were made between the two breeds and between the feeding treatments. The results from treatments $L, H$ and $H S$, all three of which received the same quantity of protein expected to be limiting for both breeds, were analysed using the General Linear Model (GLM) in Minitab (1989) Release 7.1 because of the slightly unequal subclass numbers. The live weight of the pigs at the start of the experiment was used as a covariate in the case of the final weights. The main hypothesis was that on these three treatments the protein gain would be the same for the two breeds used.

As for previous experiments (Kyriazakis \& Emmans, 1992a, b; Kyriazakis et al. 1994), the lipid values used in the analysis were derived from the equation:

$$
\operatorname{lipid}(\mathrm{g} / \mathrm{g} \mathrm{DM})=\frac{\mathrm{GE}(\mathrm{kJ} / \mathrm{g} \mathrm{DM})-(23.8 \times 6.25 \times \mathrm{N}(\mathrm{g} / \mathrm{g} \mathrm{DM}))}{39.6},
$$

which ignores, as is conventional, the small and unknown contribution of carbohydrate to the energy content.

\section{RESULTS}

The compositions of the initial-slaughter groups at 15.62 and 16.08 (sED 0.173 ) $\mathrm{kg}$ live weight were $(\mathrm{kg}$ ): empty-body weight 14.56 and 14.71 (SED 0.503 ), protein 2.256 and $2 \cdot 180$ (SED 0.079), lipid 1.422 and 2.310 (SED 0.170), ash 0.415 and 0.396 (SED 0.024) and water 10.27 and 9.59 (SED 0.370) for the LW $\times$ and CM pigs respectively. The difference in lipid content of $0.888 \mathrm{~kg}$ between the two breeds was highly significant $(P<0.001)$ and the difference in water content approached significance $(P=0 \cdot 1)$. The $\mathrm{LW} \times$ pigs also had a lower gut-fill than the CM pigs: the values were 1.058 and 1.368 (SED $0.137 ; P<0.05) \mathrm{kg}$ respectively.

The $\mathrm{LW} \times$ and CM pigs given $a d$ lib. access to feed B took 27.8 and 26.7 (SED 1.44) d respectively to consume their allowance of $33.957 \mathrm{~kg}$. At the end of this period $\mathrm{LW} \times$ were 


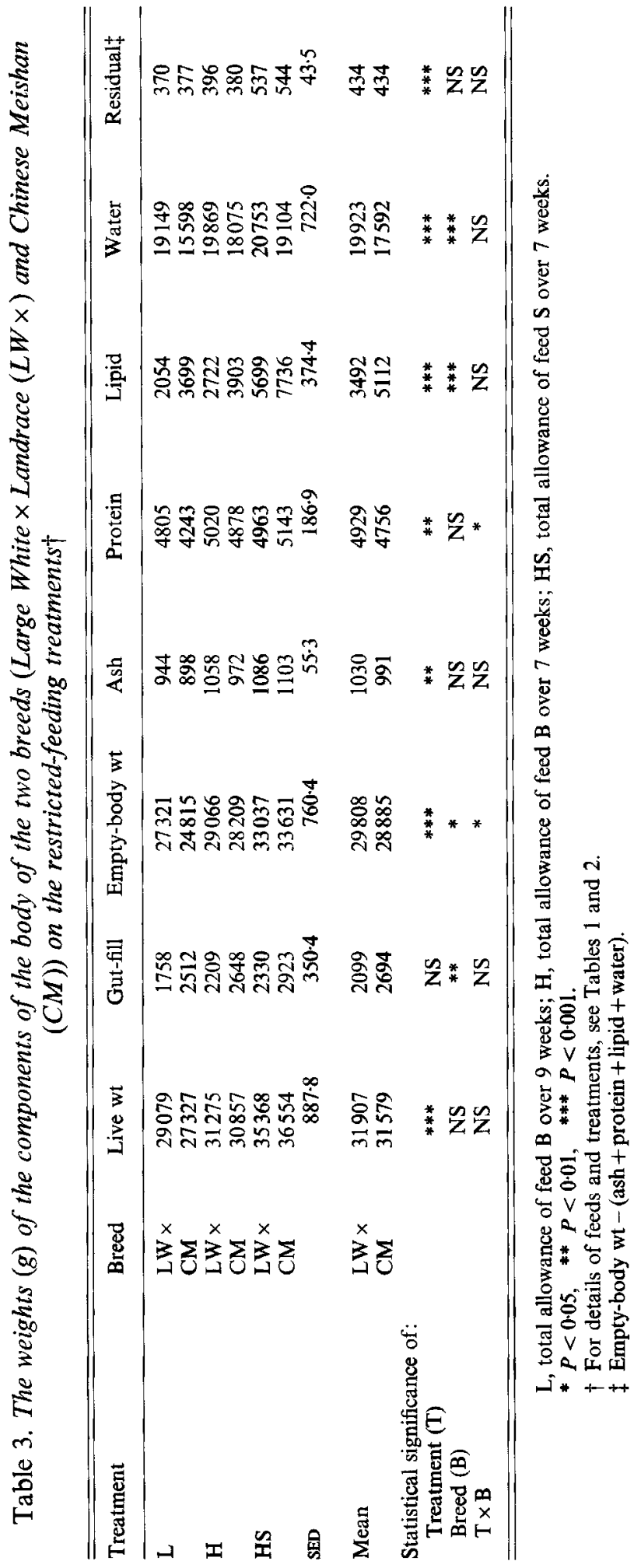




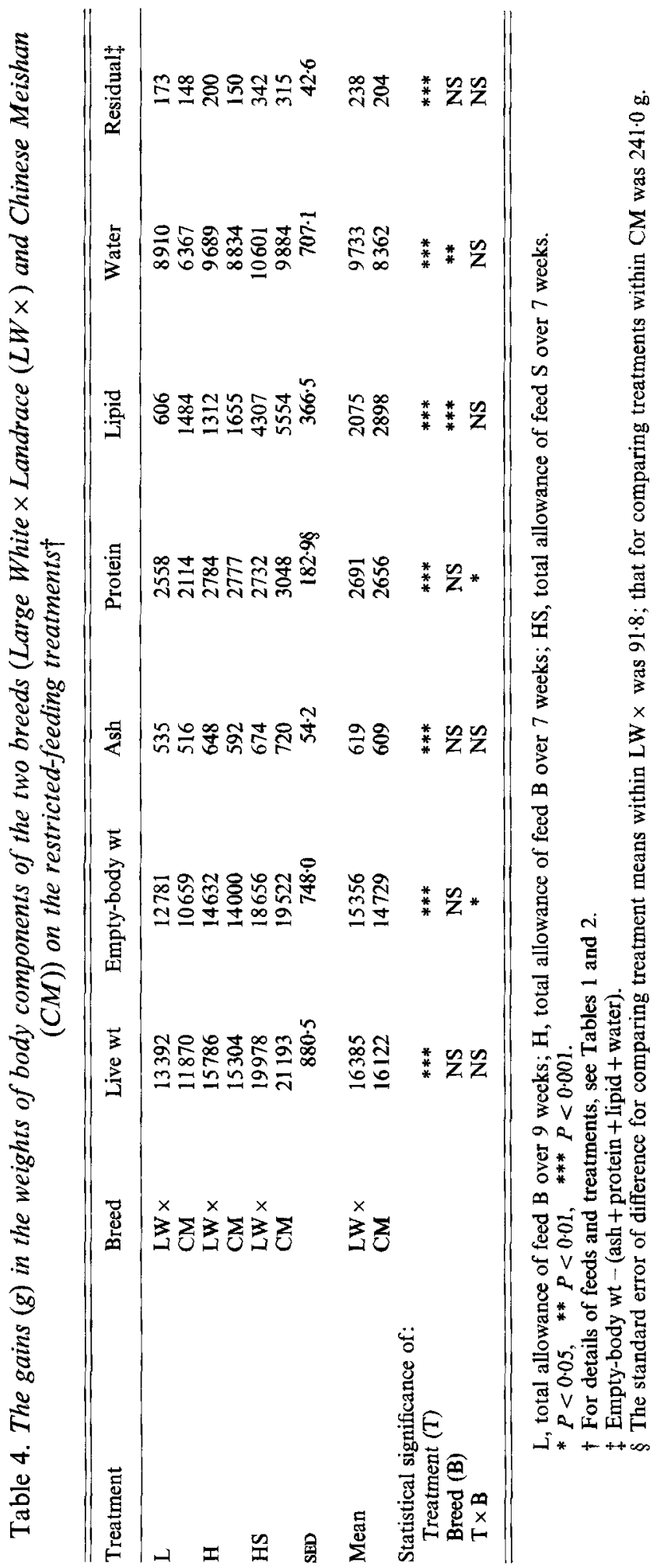




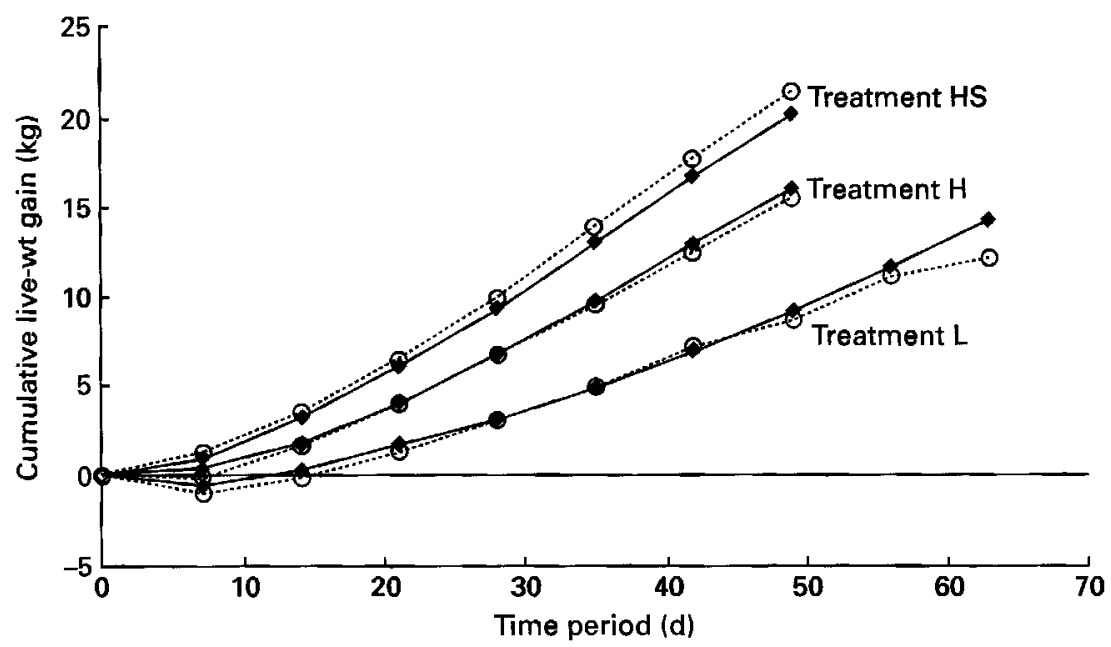

Fig. 1. The cumulative live-weight gain (kg) $v$. time period for Large White $\times$ Landrace $(\mathrm{LW} \times ;$ Meishan (CM; O) pigs on the three restricted-feeding treatments: the same total allowance of feed $(33.597 \mathrm{~kg})$ over a period of 7 weeks $(\mathrm{H})$, over a period of 9 weeks $(\mathrm{L})$, or the same allowance supplemented with starch over a period of 7 weeks (HS). For details of the diets and treatments, see Tables 1 and 2 and p. 186.

heavier than CM pigs $(33.45$ v. 29.29 (SED 0.821$) \mathrm{kg} ; P<0.001)$ and their empty-body weights of 31.71 and 27.03 (SED 0.780 ) $\mathrm{kg} ; P<0.001$ contained significantly more protein $(5.197$ v. 4.176 (SED 0.192) kg; $P<0.01$ ), more water $(21.11$ v. 16.26 (SED 0.471) kg; $P<0.001)$ and less lipid (3.988 v. 5.432 (SED 0.252$) \mathrm{kg} ; P<0.001)$ respectively. There was also a difference in their gut-fill $(1.778 v .2 .267$ (SED 0.292) $\mathrm{kg}$ ) for the $\mathrm{LW} \times$ and CM pigs respectively, but this failed to meet significance.

The composition of the bodies of the $\mathrm{LW} \times$ and $\mathrm{CM}$ pigs on the three controlled feeding treatments (L, H and $\mathrm{HS}$, on each of which the two breeds received the same quantity of protein in the same time, with the time differing between treatments $\mathrm{H}+\mathrm{HS}$ and $\mathrm{L}$ ) at the end of the experiment are given in Table 3. There were highly significant effects of feeding treatment on the empty-body weights and on the weights of the components of the empty body of the pigs slaughtered at the end of the experiment. The significant effects were due to the performance of the animals on treatment $L$ being poorer than those for the other two treatments. There were no significant $(P>0.05)$ differences in the weights of protein, ash and water between pigs on treatments $\mathrm{H}$ and $\mathrm{HS}$. Pigs given the allowance supplemented with extra energy (HS) had, as expected, significantly more lipid and, as a consequence, were heavier in terms of their empty-body weights $(P<0.001)$.

Pig breed did not affect significantly the final live weight or the weights of protein or ash at slaughter. However, LW $\times$ pigs had significantly less lipid $(P<0.001)$, and more water $(P<0.001)$, in their empty bodies than CM pigs. The only significant interaction of any importance between pig breed and feeding treatment was that on the protein weight of the pigs. This was due to the slightly lower protein weight of $\mathrm{CM}$ pigs on treatment $\mathrm{L}$ and their slightly higher weights on treatment HS, as described more fully later (p. 191).

The total gains of empty body, protein, ash, lipid and water of all pigs on treatments $\mathrm{L}$, $H$ and HS are in Table 4. (The difference between the gains and the final weights of the components are not exactly the same for all treatments as the mean initial live weights differed a little between treatments.) The cumulative weight gains over time for these pigs are shown in Fig. 1. Pigs on treatment L gained significantly less $(P<0.001)$ of all the components. There were no appreciable differences between the gains of the pigs on 
treatments $\mathrm{H}$ and $\mathrm{HS}$, other than for lipid, showing that the efficiency of using protein was not limited by the energy supply on treatment $\mathrm{H}$. The main effect of pig breed on the gains of live weight, empty body, or ash was not significant. The effect of breed was significant, however, on the gains of lipid and water, with $\mathrm{LW} \times$ pigs gaining more water and less lipid than CM pigs.

The main effect of breed on protein gain was not significant but the interaction of breed and the three restricted-feeding treatments was at $P<0.05$, Table 4 . On treatment $\mathrm{L}$ the LW $\times$ pigs gained more protein than did the CM pigs, while on $\mathrm{HS}$ the $\mathrm{CM}$ pigs gained more protein than did the $\mathrm{LW} \times$ pigs. For protein gain $(\mathrm{g} / \mathrm{pig})$ the comparison of breeds, and the assessment of the significance of the interaction between breed and the three restricted-feeding treatments, was complicated by the residual mean square for the $\mathrm{LW} \times$ pigs being significantly $(P<0-01)$ less at 21072 than that for the CM pigs of 139449 when the two breeds were analysed separately. As the test used assumes homogeneity of variance it may well be that the reality of the interaction between the three feeding treatments and the two breeds is only apparent and that the rejection of the null hypothesis of no interaction may be spurious.

\section{DISCUSSION}

The main aim of the experiment was to test the proposition that the two kinds of pigs used would retain the same amount of protein when given the same allowances of the same feed in the same time, where the allowances were limiting the rate of protein gain of both. The design used was seen as being that which would allow the breed comparison, which was of most interest, to be made in the most straightforward way. The mean protein gains of the two breeds on average across treatments $\mathrm{L}, \mathrm{H}$ and $\mathrm{HS}$ were such that the proposition could not be rejected. The standard error of the difference in the mean protein gain between the two breeds was only $0.1056 \mathrm{~kg}$ which was applied to the mean values of 2.693 and $2.655 \mathrm{~kg}$ for the $\mathrm{LW} \times$ and $\mathrm{CM}$ pigs respectively. Had there been a real main effect of breed on the amount of protein gained between the two breeds when given the same limiting diets, then this could only have been a small one and less than the $10 \%$ set by the power of the design of the study. The variance observed, however, with the CM pigs was quite large and this has attenuated the power of the study.

There was a small, but formally significant $(P<0.05)$, interaction between breed and the three restricted-feeding treatments. The direction of this interaction was such that the $\mathrm{LW} \times$ pigs had greater gains than the CM pigs on the $\mathrm{L}$ treatment, and lower gains on the HS treatment, with no effect on $\mathbf{H}$. While the interaction was formally significant it is difficult to propose a biological hypothesis that would account for it. As described on p. 191, its statistical significance must be in doubt because of the heterogeneous variance between breeds. Its consequence is that $\mathrm{LW} \times$ pigs are slightly more efficient than $\mathrm{CM}$ pigs when the protein allowance is low, but slightly less efficient when the protein allowance is high, but still limiting for both. Where breed effects on efficiency are proposed (e.g. Campbell \& Taverner, 1988) the prediction is that the difference in favour of the breed with the greater potential rate of protein retention will increase as the rate of protein allowance is increased. The direction of the interaction observed here is in the opposite direction. Further studies would be required to establish whether it has biological significance.

The fact that the two pig breeds used were very different genetically was demonstrated by the performance of the pigs given $a d$ lib. access to feed B. The CM pigs had a slower rate of protein gain, and a faster rate of lipid gain, than $L W \times$ pigs. These findings were consistent with those of previous experiments that have compared these two pig breeds under ad lib. feeding conditions (e.g. Haley et al. 1992; Kanis et al. 1992; Kyriazakis et al. 1993) and under 'choice-feeding' conditions (Kyriazakis et al. 1993). However, the rates of 
both live-weight and protein gain achieved by both breeds in the present experiment were slightly lower than those in previous experiments. This is likely to be due to the higher ambient temperature deliberately used in the present experiment. The temperature was chosen to be $22^{\circ}$ (compared, for example, with $16^{\circ}$ in the experiment of Kyriazakis et al. 1993) so that the pigs given restricted access to the feed would not be cold (see p. 187).

The condition necessary for the experiment was that the diets given to the pigs would limit the protein retention of both breeds and would, at the same time, be slightly lower than those needed for the potential rate of protein retention of the CM pigs to be attained, and appears to have been met. The rate of protein gain achieved by the CM pigs on treatments $\mathrm{H}$ and $\mathrm{HS}$ was on average $59 \mathrm{~g} / \mathrm{d}$, which was lower than the gain achieved by the CM pigs on the AL treatment at $75 \mathrm{~g} / \mathrm{d}$, although this estimate was based on only a few pigs. In a previous experiment (Kyriazakis et al. 1993) where CM pigs were allowed to choose their diet from two feeds offered as a choice, and thereby presumably to exhibit their inherent potential for protein retention, the mean PR was slightly over $90 \mathrm{~g} / \mathrm{d}$.

The implication of the finding that, on average across the three restricted-feeding treatments, the pigs of the two breeds retained essentially the same amount of protein when given the same feed allowance in the same period of time is that the pigs of both breeds retained protein with the same material efficiency. Given also that the ME:DCP ratio for both experimental feeds used was well above that estimated by Kyriazakis \& Emmans $(1992 b)$ to be the critical one for maximum efficiency, then the expectation is that the pigs used the feed protein with maximum efficiency in all three feeding treatments. The efficiency of utilization of ideal protein, $e_{p}$, can be estimated from the equation:

$$
e_{p}=\text { protein retention/(protein supply-protein for maintenance). }
$$

The protein for maintenance is calculated as the product of the mean body-protein weight $(\mathrm{kg}$ ), the time (d) and a coefficient assumed to have the value of $0.004 \mathrm{~kg}$ ideal protein $/ \mathrm{kg}$ body protein per $\mathrm{d}$. The mean body-protein weight was calculated as the simple mean of the initial and final body-protein weights. The protein supply was expressed as ideal protein (Agricultural Research Council, 1981) calculated from the rate of feed intake, the feed protein content and the estimated values for the digestibility of the CP $(0.83 \mathrm{~kg} / \mathrm{kg})$ and the value of the digested protein in relation to ideal protein $(0 \cdot 76)$, with lysine as the first limiting amino acid in the feed (see p. 186). The calculated values of $e_{p}$ were not significantly $(P>0.05)$ affected by treatment or breed with mean values of 0.785 and 0.760 (SED 0.032 ) for the $L W \times$ and the $C M$ pigs respectively. These values were slightly lower than, but not significantly different from, the maximum $e_{p}$ values observed for $\mathrm{LW} \times$ and CM pigs in the experiments of Kyriazakis \& Emmans (1992b) and Kyriazakis et al. (1994) respectively. They provide further support for the view that the material efficiency with which the ideal protein supply above maintenance is used is independent of pig genotype.

The amounts of protein and ash retained by pigs on the three treatments where protein intake was limiting were independent of pig breed, but there were highly significant effects of breed on the amounts of water and lipid gained. The $\mathbf{L W} \times$ pigs retained significantly more water than the CM pigs on all treatments, so that the water:protein ratio in their empty bodies was higher than that of the CM pigs. This finding is likely to reflect the greater degree of protein maturity, at the same protein weight, of the CM pigs, in the manner discussed by Emmans \& Kyriazakis (1995). There it is shown that if (1) the water: protein ratio at maturity is similar across genotypes and breeds of pigs and, (2) the mature protein weight of the CM pigs is lower, then the bodies of these pigs would also be expected to contain less water than those of $\mathrm{LW} \times$ at the same protein weight.

Despite the CM pigs having the same protein gain and the same live-weight gain (Fig. 1) on the same feed allowances as the LW $\times$ pigs, they nevertheless gained significantly 
more lipid. Among the many formally possible reasons for this, two are worth considering. The first is that the CM pigs have a lower maintenance requirement for energy, where maintenance, as is conventional, includes the cost of physical activity. It was noticed, but not recorded in any systematic way, that the CM pigs spent more time lying than the $\mathrm{LW} \times$ pigs and were generally quieter and less active on the three restricted-feeding treatments. Although not exactly comparable, this is consistent with the observations of Mormède \& Dantzer (1992) on CM pigs.

The quantitative difference in the energy needed for maintenance necessary to account for the different lipid retentions can be estimated using the equation of the Agricultural Research Council (1981) as a starting point. The energy for the maintenance of $1 \mathrm{~kg}$ live weight $^{0.63} / \mathrm{d}(m ; \mathrm{kJ})$ is estimated from their equation as:

$$
m\left(\mathrm{~kJ} / \mathrm{kg} \text { live weight }{ }^{0.63} \text { per } \mathrm{d}\right)=(\mathrm{MEI}-(45.9 \mathrm{PR}+53.5 \mathrm{LR})) / \mathrm{W}^{0.63},
$$

where MEI is ME intake ( $\mathrm{kJ} / \mathrm{d}), \mathrm{PR}$ is protein retention $(\mathrm{g} / \mathrm{d}), \mathrm{LR}$ is lipid retention $(\mathrm{g} / \mathrm{d})$ and $\mathrm{W}$ is the mean live weight $(\mathrm{kg})$. The values of $m$ were estimated for all pigs on the controlled feeding treatments as 712 (SE 18.2, n 15) and 606 (SE 18.4, $n 15$ ) $\mathrm{kJ} / \mathrm{kg}$ live weight $\mathrm{t}^{0.63}$ per $\mathrm{d}$ for the $\mathrm{LW} \times$ and $\mathrm{CM}$ pigs respectively. The difference of $105 \mathrm{~kJ} / \mathrm{kg}$ live weight $^{0.63}$ per $\mathrm{d}$ had a standard error of 25.6 and was, thus, highly significantly $(P<0.001)$ greater than zero. The greater lipid gain of the CM pigs could be accounted for by their having $(606 / 712)=0.85$ of the maintenance energy cost of the $\mathrm{LW} \times$ pigs. The mean value of $712 \mathrm{~kJ} / \mathrm{kg}$ live weight ${ }^{0.63}$ per $\mathrm{d}$ for the $\mathrm{LW} \times$ pigs is close to the value of $719 \mathrm{~kJ} / \mathrm{kg}$ live weight ${ }^{0.63}$ per $d$ in the Agricultural Research Council (1981) equation and not significantly different from it.

The second possibility is that the CM pigs were extracting more energy from a unit of feed than were the LW $\times$ pigs. Février et al. (1992) found that CM pigs digested between 1.02 and 1.05 times the amount of energy than did LW pigs with the higher ratio found for more fibrous feeds. In view of this the ME values that the feeds needed to have in order to be consistent with the equation of the Agricultural Research Council (1981) were calculated for each pig. The mean value for the CM pigs was 14.0 and that for the $\mathrm{LW} \times$ pigs was $13.1 \mathrm{MJ} / \mathrm{kg}$; the standard error of difference was 0.24 so that the difference was significant $(P<0.001)$. The ratio of the two values of 1.07 is somewhat higher than would be expected for feeds such as those used here on the basis of the results of Février et al. (1992). The value of $13.1 \mathrm{MJ} / \mathrm{kg}$ estimated for the $\mathrm{LW} \times$ pigs is very close to those of 12.8 and $12.9 \mathrm{MJ} / \mathrm{kg}$ estimated for the feeds used by the equation of Batterham (1990).

Given the previous calculations it seems likely that the greater lipid retention seen in the CM pigs is due, in part, to their digesting the feed better and, in part, to their having a lower energy requirement for maintenance through a lower level of physical activity.

The CM pigs of Février et al. (1992) also had a slower rate of passage of their digesta than LW pigs, which could help to explain the higher gut fill values of the CM pigs given the same feed allowance as $\mathrm{LW} \times$ pigs seen in our experiment.

There has been considerable debate about whether different pig genotypes use limiting protein with the same, or different, efficiencies (Fuller et al. 1982; Ellis et al. 1983; Campbell \& Taverner, 1988; Kyriazakis et al. 1994). While it clearly cannot be established in any general way that there are no differences between genotypes, the evidence reported here strongly supports the view that, in models of pig growth, it is safe to assume that the efficiency is the same for different kinds of pigs. There are two reasons for this. First, if there really is a difference in the main efficiency between the two breeds used here it must be trivially small; the virtually identical values of daily protein gains averaged across the three restricted-feeding treatments of $51 \cdot 1$, and $50 \cdot 9 \mathrm{~g} / \mathrm{d}$ for $\mathrm{LW} \times$ and CM pigs respectively had a standard error of difference of only $2 \cdot 10 \mathrm{~g} / \mathrm{d}$. Second, the breeds of pig used were chosen 
to be as different as was attainable. Given no difference beween the $\mathrm{LW} \times$ pigs, which have been intensively selected for high lean-growth rate and low lipid content, and the CM pigs which, as an unimproved pig breed, grow protein slowly and are much fatter on ad lib. feeding, it is difficult to see how differences among modern commercial genotypes could reasonably be expected to be present.

In order to test properly the view that two or more breeds do have the same efficiency of using scarce protein it is essential that the treatments applied are limiting for both breeds at all times during the experiment. It is possible that this condition has not always been met in experiments (e.g. Ellis et al. 1983; Campbell \& Taverner, 1988) where breed differences have been inferred. It becomes increasingly hard to be sure that this condition has been met where the experiment is over a wide range in live weight, and where the levels of feeding cannot reasonably be presumed to be limiting at all times for the different breeds used. It is unlikely that feeding on some scale related to live weight, as has been conventional in such experiments, will result in the necessary condition being met. It is not possible to find from the published results whether, and if so for how long, protein supply was not limiting protein retention in experiments such as that of Campbell \& Taverner (1988). The problems raised by the results of that experiment, including the very low efficiency of protein use, have been fully discussed by Kyriazakis et al. (1994).

This work was supported by BOCM Pauls Ltd; SAC also receives support from the Scottish Office Agriculture and Fisheries Department. The authors would like to acknowledge the help of Dr C. A. Morgan with the formulation of the feeds.

\section{REFERENCES}

Agricultural Research Council (1981). The Nutrient Requirements of Pigs. Slough: Commonwealth Agricultural Bureaux.

Batterham, E. S. (1990). Prediction of the dietary energy value of diets and raw materials for pigs. In Feedstuff Evaluation, pp. 267-281 [J. Wiseman and D. J. A. Cole, editors]. London: Butterworths.

Campbell, R. G. \& Taverner, M. R. (1988). Genotype and sex effects on the relationship between energy intake and protein deposition in growing pigs. Journal of Animal Science 66, 676-686.

Emmans, G. C. (1988). Genetic components of potential and actual growth. In Animal Breeding Opportunities. British Society of Animal Production Occasional Publication no. 12, pp. 153-183. Edinburgh: BSAP.

Emmans, G. C. \& Kyriazakis, I. (1995). A general method for predicting the weight of water in the empty bodies of growing pigs. Animal Science (In the press).

Ellis, M., Smith, W. C., Henderson, R., Whittemore, C. T., Laird, R. \& Phillips, P. (1983). Comparative performance and body composition of control and selection line Large White pigs. 3 . Three low feeding scales for a fixed time. Animal Production 37, 253-258.

Février, C., Bourdon, D. \& Aumaitre, A. (1992). Effects of level of dietary fiber from wheat bran on digestibility of nutrients, digestive enzymes and performance in the European Large White and Chinese Meishan pigs. Journal of Animal Physiology and Animal Nutrition 68, 60-72.

Fuller, M. F. \& Garthwaite, P. (1993). The form of response of body protein accretion to dietary amino acid supply. Journal of Nutrition 123, 957-963.

Fuller, M. F., Gordon, J. C. \& Aitken, R. (1982). Energy and protein utilisation of pigs of different sex and genotype. In Energy Metabolism of Farm Animals. European Association of Animal Production Publication no. 29, pp. 169-174. Switzerland: Vitzean.

Haley, C. S., d'Agaro, E. \& Ellis, M. (1992). Genetic components of growth and ultrasonic fat depth traits in Meishan and Large White pigs and their reciprocal crosses. Animal Production 54, 105-115.

Kanis, E., van der Steen, H. A. M., de Groot, P. N. \& Brascamp, E. W. (1992). Growth, feed intake and body composition of Meishan pigs compared to Western genetic types. In Symposium sur le Porc Chinois, pp. 215-225 [M. Molenat and C. Legault, editors]. Jouy-en-Josas, France: Institut National de la Recherche Agronomique.

Kyriazakis, I., Dotas, D. \& Emmans, G. C. (1994). The effect of breed on the relationship between feed composition and the efficiency of protein utilization in pigs. British Journal of Nutrition 71, 849-859.

Kyriazakis, I. \& Emmans, G. C. (1992a). The effects of varying protein and energy intakes on the growth and body composition of pigs. 1. The effects of energy intake at constant, high protein intake. British Journal of Nutrition 68, 603-613. 
Kyriazakis, I. \& Emmans, G. C. (1992b). The effects of varying protein and energy intakes on the growth and body composition of pigs. 2 . The effects of varying both energy and protein intake. British Journal of Nutrition 68, 615-625.

Kyriazakis, I., Leus, K., Emmans, G. C., Haley, C. S. \& Oldham, J. D. (1993). The effect of breed (Large White $\times$ Landrace vs purebred Meishan) on the diets selected by pigs given a choice between two foods that differ in their crude protein contents. Animal Production 56, 121-128.

Minitab (1989). Release 7.1. Minitab, Inc.: Pennsylvania State College.

Mormède, P. \& Dantzer, R. (1990). Adaptive abilities of Chinese pig breeds. In Symposium sur le Porc Chinois, pp. 156-165 [M. Molenat and C. Legault, editors]. Jouy-en-Josas, France: Institut National de la Recherche Agronomique.

Whittemore, C. T. (1983). Development of recommended energy and protein allowances for growing pigs Agricultural Systems 11, 159-186.

Whittemore, C. T. \& Fawcett, R. H. (1974). Model responses of the growing pigs to dietary intake of energy and protein. Animal Production 19, 221-231.

Whittemore, C. T. \& Fawcett, R. H. (1976). Theoretical aspects of a flexible model to simulate protein and lipid growth in pigs. Animal Production 27, 87-96.

Whittemore, C. T., Tullis, J. B. \& Emmans, G. C. (1988). Protein growth in pigs. Animal Production 46, 437-445.

Whittemore, C. T. (1994). Growth and the simulation of amimal responses. In Principles of Pig Science, pp. 55-73 [D. J. A. Cole, J. Wiseman and M. A. Varley, editors]. Nottingham: Nottingham University Press. 